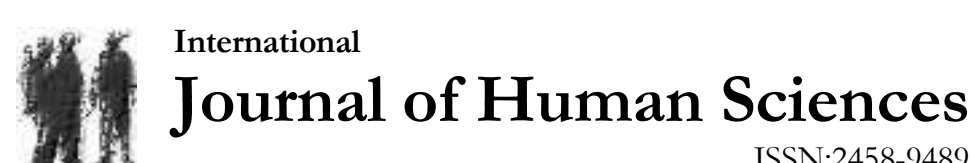

Volume 16 Issue 2 Year: 2019

\section{Health, news and ethical principles}

\section{Sağlık, haber ve etik ilkeler ${ }^{1}$}

\begin{abstract}
Health news has a special position due to both their corporate significance and being for the special/private areas of the readers. They also directly influence the health right, which is one of the fundamental, irreplaceable, nontransferable rights of the individual and based on the "value of being human". The health news which is made inattentively or false can lead to ending an individual's life or reducing the life quality of an individual.

In this regard, in this study, which aims to reveal the ethical principles of health journalism in Turkey within the framework of social responsibility theory in relation to health journalism which requires a privileged responsibility and attention, a qualitative approach was adopted where the data was collected through document analysis and interviews.
\end{abstract}

As a result, the health journalist needs to observe personal rights and act responsibly in order to avoid disrupting the body unity of a person, adversely affect the life quality of a person and avoid preventing the right to access to equal and quality health services in his professional journalist behaviors while producing news. Within this framework, the Ethical Principles of Health Journalism which should be taken into consideration by the journalist in the production process of the health news are as follows: Principle of not

\section{Özet}

Sağlık haberleri hem taşıdıkları kamusal önem hem de okuyucuların özel/mahrem alanlarına yönelik olmaları nedeniyle özel bir konuma sahiptir. Aynı zamanda kaynağını insanın "insan olma değeri"nden alan ve bireyin temel, vazgeçilemez, devredilemez haklarından biri olan sağlık hakkııı doğrudan etkilemektedir. Özensiz, eksik veya yanlış yapılan bir sağlık haberi, bireyin yaşamının sonlanmasına veya yaşam kalitesinin düşmesine neden olabilmektedir.

Bu bağlamda ayrıcalıklı bir sorumluluk ve özen gerektiren sağllk haberciliği ile ilgili olarak, Türkiye'de sağllk haberciliği etik ilkelerinin ortaya konulması amaçlandığı çalışmada, verilerin doküman incelemesi ve görüşme yoluyla toplandığ1 nitel yaklaşım benimsenmiştir.

Sonuç olarak sağlık habercisinin haber üretiminde profesyonel gazetecilik davranışlarının gereğiyle, kişinin vücut bütünlüğunü bozmamak, yaşam kalitesini olumsuz etkilememek, eşit ve kaliteli sağlık hizmetine ulaşma hakkını engellememek adına, kişilik haklarını da gözeterek, sorumlu davranmasının gerekliliği ortaya çıkmaktadır. Bu çerçevede gazetecinin sağllk haberi üretim sürecinde göz önünde bulundurması gereken Sağlık Haberciliği Etik İlkeleri; zarar vermeme ilkesi, doğruluk ve objektiflik ilkesi, mahremiyet

\footnotetext{
1 Çalışma, Anadolu Üniversitesi Bilimsel Araştırma Projeleri Komisyonunca kabul edilen 1208 E 127 nolu proje kapsamında desteklenen, Anadolu Üniversitesi Sosyal Bilimler Enstitüsü tarafindan kabul edilen "Sağlık Konulu yayıncılıkta Etik İlkeler" başlıklı doktora tezinden hazırlanmıştır.

2 Öğr. Gör. Dr., Eskişehir Teknik Üniversitesi, Porsuk MYO, asumankaya@,eskisehir.edu.tr

ID: https://orcid.org/0000-0003-3074-0643
} 
harming, principles of honesty and objectivity, ve özel hayat ilkesi, hakkaniyet ilkesi olarak principles of privacy and private life, principle of belirlenmiştir. equity.

Anahtar Sözcükler: Sağlık; habercilik; meslek

Keywords: Health; journalism; professional etiğ̈i; sağllk habercilik etiği; etik ilke. ethics; health journalism ethics; ethical principle.

(Extended English summary is at the end of $\underline{\text { this document) }}$

\section{Giriş}

Kendi içerisinde ve birbiriyle etkileşimde bulunan ve aynı zamanda birçok toplumsal sisteme dahil olan birey, toplumun düşünce, yarg1 ve inançları olarak tanımlanabilecek kültür sistemi içerisinde varlığını sürdürmektedir. Bireyin dahil olduğu kültür sisteminin sürekliliği içinse, kültür sisteminin içerisinde bir iletişim sürecinin yaşanması gerekmektedir. Kitle iletişim araçları, günümüzde sahip oldukları güç ve etki doğrultusunda yaşantımızın ayrılmaz bir parçası haline gelmiş; toplumda ortak değer yargılarının, düşünce ve davranış biçimlerinin öğrenilmesinde, diğer bir ifade ile toplumsallaşma sürecinde roller üstlenmiştir. Kitle iletişim araçlarının kültürel değişim üzerindeki etkisini Aytaç $(2005,97)$, "Medya kültürü, bir toplumun sadece kültür sisteminin değil tüm sisteminin, belli bir durumun yapılanmasına, ayakta kalmasına veya değişmesine medyanın katkısını ifade etmektedir" sözleri ile belirtmektedir.

Kültürel değişimleri etkileyebilme gücüne sahip olan medya, sağlıklı, uzun bir yaşam geçirmek isteyen bireylerin ilgilerini çekebilmekte ve davranışlarını yönlendirebilmektedir. İnsanlar sağlıkla ilgili gelişme ve bilgileri genellikle medyadan öğrenmekte, medya da insanların bu ilgisine karşıllk vermektedir. Demir'e $(2008,3)$ göre, basında çıkan haberler arasında sağlık haberlerinin okunurluk oranı \%14'lük bir payla ilk sırada yer almakta ve dolayısıyla, okuyucular en çok sağlik haberlerinden etkilenmektedir. Karagöz de (2009, 192), sağlık konusunda bilgi aktarılırken bireylerin tutumların, kanaatlerini ve tavır alışlarının şekillenmesini sağlayan medyanın önemini vurgulamakta ve medyayı birincil kaynak olarak işaret etmektedir.

Medya için sağlık konulu haberler, sağlığın insan yaşamındaki önemi nedeniyle değerli olması nedeniyle artış gösterme eğilimindedir. Bu artışla birlikte, kamuoyuna aktarılan bilgilerin doğruluğu, güvenilirliği ve geçerliliği anlamındaki kaygılar da aynı oranda artmaktadır. Özellikle salgın hastalıklar, alternatif tıp ve şifalı bitkiler vb. konulardaki yanlış bilgilendirmeler, geri dönüşü zor ya da olanaksız olumsuz etkiler birakabilmektedir.

Kaya, Yüksel ve Öğüt $(2011,63)$ "Sağlık Haberlerinde Mucize Tedaviler" başlıklı araştırması ile sağlık konulu haberlerde meslek ahlak ilkelerine ne derecede uyulduğunu ortaya koymaktadır. İncelenen haberlerin \%68'inde "mucize" kavramının olumlu, kabul eden, doğrulayan, umut vaat eden ve öven nitelikte kullanıldığının, beslenme/güzellik/ sağlıklı yaşam temalarının mucize bitki, mucize ilaç, mucize diyet gibi ifadelerle birlikte umut sunduğunun ve etik açıdan bu durumun sorunlu bulunduğun altı çizilmektedir. Kaya ve Güler'in $(2012,92)$ "Basında Organ Nakli Haberlerinin Sunumu" başlıklı çalışmasında da organ nakli ile ilgili haberlerin nasıl sunulduğu ortaya konulmakta ve sağlık haberlerinin güvenirliğinin bir kez daha sorgulanması gerektiği ve meslek etik ilkelerinin gerekliliğinin ifade edilmektedir.

Sağlık yayıncllı̆̆ üzerine TÜBİTAK ve Anadolu Üniversitesi Bilimsel Araştırma Projeleri Komisyonu'nun desteği ile tamamlanmış olan “Türkiye'de Sağllk Konulu Yayıncllk İlkelerinin Belirlenmesi: Kaynak, İleti ve Hedef Kitle Bağlamında Sağlık Konulu Yayınların Analizi” başlıklı projenin sonuç raporunda sağlık haberlerinin etik boyutu ile ilgili olarak "medya profesyonellerinin bu tür haber içerikleri konusunda vatandaşın algısını dikkate alarak, daha hassas olmaları yolunda bir uyarı yapılmasını gerekli kılmaktadır (Yüksel vd., 2013, 472)" ve haberlerin denetimiyle ilgili olarak da "Vatandaşlar arasında ise neredeyse her iki kişiden biri sağlık konulu yayınların "denetimsiz" 
olduğunu düşünmektedir. [Çözüm önerileriyle ilgili olarak] medya ve sağlık profesyonellerinin bir kısmı mevcut yasal düzenlemelerin yetersiz olduğunu, yeterince uygulan(a)madığını ve gerekiyorsa da daha başka yasal düzenlemelere gidilebileceğini ifade etmektedirler (Yüksel vd., 2013, 473)" denilmektedir.

Sağlık haberciliğinin işlevlerini temelde insanların sağlık konusunda aydınlatılması, halk sağlığ1 konusunda farkındalık yaratılması ve bilinçlendirilmesi şeklinde belirlemek; konusunu ise t1p alanındaki yeni keşifler, sağlık sektörüne ilişkin gelişmeler, yaygın hastalıkların ülkede ve dünyadaki seyri, yaşanan ilginç olaylar, yapılan yasal düzenlemeler, kişisel öyküler vb. olarak çerçevelemek mümkündür (İşak, 2008, 26; Baydur, 2010, 72; Öğüt, 2013, 40). Bu bağlamda, sağlık habercilerinin okuyucuya daha fazla ulaşmak adına kullanmış oldukları teknikleri Friedman, Tanner ve Rose (2014, 383) şu şekilde sıralamaktadırlar: Uzman görüşmeleri, dikkat çekici başlıklar, güçlü gelişen olaylar, sosyal medya ile desteklenen olaylar ve kişisel hikâyeler. İster kişisel hikâyeleri ele alsın isterse hukuksal mevzuatı, göz ardı edilmemesi gereken nokta, sağlık haberciliğinin, aynı zamanda tıp alanını da ilgilendirdiği gerçeğidir. Bu nedenle, sağlık haberciliği yapan gazetecilerin bir açıdan gazetecilik, bir açıdan da hekim sorumluluğunu taşıdığ1 ve elbette ki topluma karşı da sorumlu olduğu unutulmamalıdır. Diğer bir ifadeyle, sağlık haberciliğinin işlevleri ve kapsamı gereği zamanında, doğru ve güvenilir haberciliğin yanı sıra, kamu güvenini ve sağlı̆ını sağlamak için özel bir sorumluluğu bulunmaktadir:

"Medya toplumda gerçeklik algılarını yaratmada, farklılaştırmada önemli bir rol oynamaktadır. Bireyler televizyonda gördükleri, gazetelerde okudukları ya da radyoda duydukları şeylere inanma eğilimindedir. Bu ise gazetecilerin omuzlarına büyük bir sorumluluk yüklemektedir. Bu nedenle hassas olan insanlar ile ilgili haber yaparken [engelli olanlar, sağlık sorunları olanlar vb.] daha özenli davranılmalı ve kullanılan klişe yaklaşım veya ifadelerin olumsuz etkileri olabileceği, toplumu yanlış bilinçlendirebileceği ve bireylerin toplum içerisinde kaliteli bir hayat sürmesine engel olabileceği göz ardı edilmemelidir (Southal, 2004, 19)".

$\mathrm{Bu}$ anlamda sağlık haberciliği ayrıcalıklı bir sorumluluk ve özen gerektirmektedir. Çünkü insanlar, sağlıkla ilgili gelişme ve bilgileri genellikle medyadan öğrenmekte ve davranış olarak sergileme eğilimindedir. Avc1 ve Sönmez (2013) de, bireylerin çeşitli konularda doyuma ulaşmak için televizyonda yayınlanan sağlık programlarını izlediğini ifade etmekte ve içeriklerden etkilenen bireylerin sağlık ve hastalıklar konusunda çeşitli davranışlara yönlendiğini ifade etmektedir.

Medyanın hedef kitle üzerindeki etkisini ortaya koymak adına verilebilecek bir örnek, MMR (kızamık, kabakulak ve kızamıkçı) aşısı ile ilgili olarak İngiltere'de yayınlanan haberler ve sonrasında yaşanan gelişmelerdir:

“1990’ların sonlarında MMR aşısı ve otizm arasındaki ilişki kanıtlanmamıs olmasına karşın ana akım medyada yer almıs ve büyük oranda sağhlk. korkusuna neden olmuştur. Bu korku [sadece haberin yayınlandığı zamanı değil sonrasındaki davranışları da kapsayacak şekilde] devam etmiştir. Bu iki olgu arasındaki bağlantıyı ortaya koymak için inandırıcı [yeterli] kanıtların eksikliğine karşın, aileler haklı olarak korkmuş ve çocuklarına MMR aşısı yaptırmaktan kaçınmıştır. Resmi istatistiklere göre bu olay [MMR aşısının otizme neden olabileceği yönündeki haberlerin yayınlanması] sonrasında kızamık hastalığında ciddi bir artış yaşanmıştır. Kızamık vakaları [nedeniyle meydana gelen] ölüm olayları çok düşük bir oranda iken, 19982008 yilları arasında, Ingiltere ve Gallerde, Health Protection Agency tarafindan 15 kızamik temelli ölüm rapor edilmiştir. [Oysa] bu ölümlerin MMR aşısı ile önlenebilmesi mümkündü (Half of medical reporting, 2012)".

Türkiye'de sağlık konulu yayıncılık alanında son yıllarda yaşanan gelişmeler iletişim bilimi alanında dikkatleri üzerine çekmiş ve bu bağlamda çeşitli çalışmalar ortaya konulmaya başlamıştır. Bu çalışmalarda sağlık haberinin/yayınlarının bireyin davranışları üzerindeki etkisi, genel olarak basın ilkeleri açısından değerlendirilmesi gibi konunun farklı boyutlarına odaklanılmaktadır. Bununla birlikte, doğrudan bireyin hayatı üzerinde etkisi olan haberlerinin hazırlanması, sunulması ile ilgili olarak sağlık haberi/yayıncılığı özelinde etik olarak nasıl davranması gerektiği ele alınmamıştur. 


\section{Ahlak, etik, meslek etiği}

Bireyler her zaman için diğer bireylerle birlikte, bir toplum veya topluluk içerisinde varllğını devam ettirmektedir. Bu devamllık, o toplumun üyeleri arasında sözlü veya sözsüz bir dil birliğini gerektirmektedir. Bu nedenle de bir toplumun üyesi olmak, her bir bireye sorumluluk ve yükümlügü de beraberinde getirmektedir. Bireye yüklenen bu sorumlulukların diğer bir ifade ile sosyal düzen kurallarının, yerine getirilmemeleri halinde toplum tarafindan tepkiyle karşılanma veya otoritenin harekete geçmesi gibi sonuçları olmaktadır. Ahlak, hukuk, din kuralları olarak sıralanan sosyal düzen kurallarının tümünün ortak özelliği; sürekli ve genel yaptırımlı buyruklar niteliğinde olmalarıdır (Erinç, 2008,16). Ahlaksal veya ahlaki davranışlar, ahlak kurallarının toplumda yaşayan her insanın yerine getirmesini öngördüğü davranışlardır. Aynı zamanda, yaptırımı vicdan ile ilgili olan ahlaksal davranışlar, "akla dayanarak değer yargıları verebilme yetisine bağlıdır, iyiyle kötüyü ayırabilmek ve bu karara göre davranabilmek demektir" (Fromm, 2006, 161).

Insanın davranış/eylemlerinin, gerçekleştirilen davranış/eylemlerin anlamlarını belirleyecek olan bir ahlaka dayanmadığı takdirde insani bir eylem niteliği kazanamayacağın belirten Piepper (2012, 47-48), bunun için de, bir ilke kavramı olarak ahlakiliği öngörmekte ve özgürlük ile ilişkilendirmektedir: "Ahlak[1n], ahlakilik kavramıyla sürekli temellendirilmesi ve meşrulaştırılması gerekmektedir. İyi olma isteğini temel tavır olarak seçmiş olan kişi, ahlaki yetkinliğe sahip demektir. Ahlaki yetkinlik sayesinde ahlaki davranan kişi, eylemlerinin gerekçelerinin hesabını verebilir; asıl gerekçede herkes adına olabilecek en fazla özgürlüğü yaratacak norm ve değerlere bağlanan özgürlüktür”.

Belirli yer ve zamana özgü olarak iyi davranışlarla kötü davranışların tanımını yapan ve kuralını ortaya koyan, aynı zamanda da değerlerle iç içe olan bir alan olarak ablak kavramı, her ne kadar etik kavramılla etimolojik olarak benzerlik taşısa da, felsefede yüklendikleri anlam bakımından farklı iki kavramdır. Ahlak, olgusal ve tarihsel olarak yaşanırken, etik, bu olguya yönelen felsefe disiplininin adı dolayısıyla ahlak felsefesi olarak tanımlanmakta ve yapılması ya da kaçınılması gerekenler konusunda her durumda geçerli olabilecek birtakım ilkeler, kurallar önermektedir. Amaçlanan ise kişilere eylemlerinde kullanabilecekleri bir ölçüt sağlanmaya çalışılmasıdır. Bu bağlamda etik, kendisi dışında kendisinden bağımsız olarak var olan eylem, ilke, normlara ilişkin bilgilerdir. Günlük dilde alıskkanlıkla ilgili bir ahlaksal problemden söz edildiğinde aslında, bunu etiğe ait bir problem olarak anlaşılması gerekmektedir (Tepe, 2011, 14; Delius, 1990, 313). Etik, bir eylemi ahlaki açıdan iyi bir eylem yapan niteliksel durumu sorgulamakta, bu özelliği ile neyin iyi ve neyin kötü olduğunu tanımlamaya çalsşan; olan ile olması gereken arasındaki ilişkiyi sorgulayan ablak felsefesi anlamına gelmektedir. Konu olarak kendinse ahlakı benimseyen etiğin amacı ise temellendirilmiş sonuçlara varmak, ahlakı açıklayarak buna bağlı olarak ilkeleri saptamaktır (Mosoley, 2011, 87; Piepper, 2012, 18).

Etik, insanlık tarihi boyunca, ortaya çıkan dönemlerin üretim biçimi, tinsel, kültürel değeri ve egemen ideolojinin değer yargiları vb. etkenlere göre, değişim ve dönüşüm gösteren bir süreç olarak gelişim göstermiştir. Uluslararası, kıtalararası ortaya çıkan savaşlar, ticari ilişkiler, dinleri yayma çabaları gibi kitlesel hareketler aynı zamanda düşünce akımlarının, kültürlerin de taşıyıcıları olmuş, savaşların toplumlarda yarattı̆̆ ekonomik ve sosyal bunalımlar, insanları içine düştükleri ahlaki bunalımları aşma arayışlarına itmiştir. Antik Çağ'dan Hıristiyanlı̆̆a, Sanayi Devrimine ve günümüze kadar yaşanan değişim ve dönüşümler etiğin gelişim sürecinde de belirleyici rol üstlenmiştir (Etik, kodlanan etik ve pratiği, 2012, 28). Bu süreç içerisinde birçok filozof farklı noktalardan yola çıkarak etik ve ahlak kavramını açıklamışlardır. Her ne kadar çıkış noktaları farklı olsa da temelde odaklanılan konular en yüksek iyi, doğru eylem ve istenç özgürlüğü olmuştur: Özellikle etik ve ahlak arasında kesin bir ayrımın yapılamadığı dönemlerde, "herkesin pratikte ulaşmayı çabaladığı şey" olarak ifade edilebilecek olan en yükesek iyi kavramı konumlandırılmıştır. Etiğin temel problemlerinden olan doğru eylem konusunda ahlaksal buyruk ve taleplerin niteliği, ahlaksal bakımdan doğru eylemin mahiyeti, ahlaksal değer yargılarının mahiyeti sorunlarılla ilgili olarak çeşitli yorum ve formüller geliştirilmiştir. Ahlaki yaşama ait olarak ahlaksal ilişki, doğruluk, yanlışlık, vicdan vb. fenomenlerin temelinde yer alan ahlaksal eylemlerin aslında, eylemde bulunan kişinin özgür kararlarına bağlı olduğu ve kişinin istediği takdirde farklı şekilde de davranabilme özgürlüğüne sahip olduğu inancı da istenç özgürlüğü çerçevesinde 
değerlendirilmiştir (Delius, 1990, 314-319; Özlem, 2010, 48). Etik davranış1 şekillendiren, dayandığı inanç ve değerlere göre toplumdan topluma farklilıklar gösteren, etik ilkelerin geliştirilmesinde temel alınan ilkeler de hakkaniyet, insan hakları, faydacılık ve bireysellik olarak sıralanmaktadır.

"Hakkaniyet ilkesi, bütün kararların tutarlı, tarafsız ve gerçeklere dayalı olması üzerinde odaklanırken insan hakları ilkesi de bireylerin varlı̆̆1, bütünlüğ̈ ve temel insan hakları üzerinde odaklanmaktadır. Herkes için en iyi olacak kararın verilmesi ise faydacılık ilkesi olarak tanımlanmaktadır. Bununla birlikte bireysellik ilkesi, bireylerin temel amaçlarının uzun dönemli olarak kişisel kazançlarını arttırmaktır. Burada uzun dönemli terimi anahtar kavramdır ve kısa dönemde fazla kazanç sağlamak için yapılan yanlış eylemleri içermemektedir (Öztürk, 1998, 95; Aydın, 2012, 23)”.

Etik, sadece özerk (kuramsal) bir bilim olarak değerlendirilmemelidir. Etik, özellikle modernleşme ve küreselleşmenin kimi alan veya durumlarda yarattı̆̆ değinimler sonucunda, 20. yüzyılın sonlarına doğru uygulamalı bir hale dönüşmüştür (Cevizci, 2013, 18; Pieper, 2012, 85). Bu bağlamda, "kuramsal tartışmalar yerine günlük yaşamda karşılaşılan ve çoğunlukla çağın bilimsel, teknolojik, ekonomik ve sosyal gelişmelerinin sonucu olarak ortaya çıkan etik sorunları merkeze alan etik çalışmalarına verilen ad (Oğuz vd., 2005, 245)" olarak tanımlanan uygulamalı etik alanları arasında biyoetik, iş etiği, siyaset etiği, çevre etiği, tıp etiği, basın etiği sayılabilmektedir.

Uygulamalı etiğin, bireyin; (1) günlük yaşam içerisinde karşı karşıya kaldığ1 ahlaki problemleri tartıştı̆̆ , analiz ettiği problem etiği ve (2) mesleğini gerçekleştirirken ihtiyaç duyduğu değer ve değer bilgisini inceleyen meslek etiği olmak üzere iki ana unsuru bulunmaktadır. Bu iki unsuruyla uygulamalı etik, teori ve pratik arasında aracılık ederek, etik teoriler yardımıyla pratiği düzenli ve anlaşlır kılmaya çalışmaktadır. Cevizci (2013, 28-34) uygulamalı etiğin iki unsuru arasındaki farklılı̆̆1 şu şekilde açıklamaktadır: Hayatın bireyi karşı karşıya bıraktığı ahlaki problemlerini tartışan, diğer bir ifadeyle gündelik veya reel hayatta karşlaşılan ahlaki sorunlarla ilgili problematiği inceleyen alan problemler etiği (vaka etiği)dir. Mesleğin iyi ve fayda sağlayacak şekilde uygulanmasını sağlayan olgu veya teknik bilgiye ek olarak ihtiyaç duyulan değer veya değer bilgisini inceleyen alan ise meslek etiğidir. Uygulamalı etiğin her iki alanında da teorik etikten alınarak kullanılan normatif teoriler ve yöntemler farkll11k göstermektedir. Ahlaki problemlere dair bir uygulamalı etik söz konusu olduğunda normatif teorilerin hepsi kullanılabilmektedir. Meslek etiklerinde ise hemen hemen tümüyle deontolojik bir etik anlayışı, kısmen de erdem etiğinin yaklaşımı benimsenmektedir. Meslek etiğinde, içselci bir yöntem ile yukarıdan aşağıya doğru diye nitelenebilecek bir akıl yürütme ve temellendirme tarzından faydalanılmakta, mesleğe ilişskin bir takım iyi, doğru ve standartlar olduğu varsayılmaktadır. Problem etiğinde ise, dışsalcı bir yöntem ile aşağıdan yukarıya doğru bir haklılandırma ve temellendirme stratejisi benimsenmektedir. Bağımsız, evrensel olarak nitelendirilecek normlar gündeme gelmekte ve çözümü belirleyen şey konunun dışındaki söz konusu felsefi, etik, sosyolojik, psikolojik perspektifler olmak durumundadır.

Bir meslek grubunu oluşturan bireylerin bir arada olmasını sağlayan temel etmen; paylaşmış oldukları kavram, değer ve ilkelerdir. Bu ilkelerin oluşumunda elbette ki mesleki deneyimler ve toplumsal yapı önemli yer tutmaktadır. Davranış normları geliştirerek, meslek alanında karşı karşıya kalınan etik sorunların önlenme çabası olarak tanımlanan meslek etiğinin en önemli yönlerinden birisi, tüm dünyada aynı meslekte çalışan bireylerin belirlenen davranış kurallarına uygun davranmasıdır (Oğuz vd., 2005, 173). Bu anlamda, hekimlik mesleği tarihte bu alanda verilebilecek en eski ve önemli örnek olarak karşımıza çıkarken, yaygın olarak bilinen bir diğer meslek de basındır. Aynı zamanda, bu iki meslek çalışmanın konusunu teşkil eden sağlık konulu yayınların da boyutlarını oluşturmaktadır. Hekimin sorumluluk alanını hasta, meslektaşları ve toplum oluştururken; basının sorumluluk alanını ise okuyucu/izleyici, toplum ve meslektaşları oluşturmaktadır. Bu çerçevede, çalışmada hem tup hem de basin alanındaki etik ilkelerin incelenmesini gerekmektedir.

\section{Tıp etiği ve basın etiği}

Hekimlik, insana sağlı̆̆ını yeniden kazandırmak amacıyla insan üzerinde gerçekleştirilen, diğer bir ifade ile uygulama alanı canlı olan bir meslektir. Bu nedenle hekim, yaptığı davranışlarda, aldığı 
kararlarda özenli olmak ve en iyi seçenekleri bulmakla yükümlüdür. Etiğin, uygulamalı etiğe yansıyan farklılaşmış uzantısı olarak tanımlanabilen tıp etiği, tup uygulaması sırasında hekim-hasta, hekimhekim, hekim kurum, hasta-sağlık politikası, denek-araştırmacı hekim vb. ilişkilerinde belirlenen "değer sorunlarıyla (Çobanoğlu, 2009, 14)" ilgilenmektedir. Trbbi etik ise "hekimlerin ve araştırıcıların çeşitli çalışmalarında uymaları gereken, hastaları ve yakınlarını bilgilendirme, hasta vücudunun bütünlüğüne sayg1 gösterme, hastanın karar vermesini sağlamaya yönelik kurallar topluluğu (Berkarda, 2004, 58)" olarak tanımlamaktadır. Tibbi etik alanında karar verilirken herhangi bir etik ilkenin bir ötekine karşı üstünlügü söz konusu değildir, gerçekleşen olay biriciktir ve durum/olayların koşullarına göre bu ilkelerden herhangi biri seçilmektedir. Beauchamp ve Childress (1994) ilkeleri sınırlandırarak, bazı ilkeleri temel ilke olarak adlandırırmıslardır (aktaran Büken ve Büken, 2002, 19; Çobanoğlu, 2009, 17). Bunlar: Yarar sağlama ilkesi, zarar vermeme ilkesi, özerkliğe saygi ilkesi ve adalet ilkesidir.

En genel tanımıyla gazetecilik mesleği ile ilgili olarak belirlenen düzenlemeleri ifade eden basın e tiğ $i$, "medyanın daha iyi hizmet sunmasını sağlamak üzere belirlenmiş olan bir dizi ilke ve kuralları içermekte (Bertrand, 2004, 10)" ve "toplumun kültürel ve ahlaki yapısı ile çelişmeyerek, evrensel insani ve ahlaki değerleri göz önünde bulundurarak, medya kurumlarının ve çalışanlarının sorumluluklarını ve görevlerini belirlemeye yönelik bir çalışma alanını (Çil, 2007, 47)" ifade etmektedir. Cevizci'ye $(2013,324)$ göre ise, "kitle iletişim araçları alanında meydana gelen ahlaki problemleri ele alan, gazetecilik veya haberciliğin kurucu değerlerini tartışan, medya çalışanlarının nasıl davranacağını belirleme noktasında yardımcı olan bir uygulamalı etik dalı" olarak tanımlanabilmektedir.

Basın konseyleri, ombudsmanlik uygulamaları ve meslek ilkelerinin temel amacinın, basın alanında çalışan gazetecilerin mesleklerini gerçekleştirirken uymaları gerekli olan kriterleri belirlemek ve sorumluluklarını hatırlatmak olarak özetlenmesi mümkündür. Gazeteci, yapmakta olduğu haberlerle "bilgilendirilmiş vatandaşlar üreterek, özellikle [bireylerin] seçim yapma süreçlerine katkıda (Çı̆̆ ve Çığ, 2011, 45)" bulunmaktadır. Bu bağlamda da, gazetecinin; topluma (okuyucu/izleyici), habere konu olan kişiye, haber kaynağına ve meslektaşlarına karşı sorumluluk taşıdığının hatırda tutulması gerekmektedir. Gazetecinin üreterek kitle iletişim araçları vasıtasıyla okuyucu/izleyiciye sunduğu bilginin üretimi esnasında dikkate alması gerekli hususlar basının temel etik ilkeleri olarak kendini göstermektedir. Bu ilkeler ise objektiflik, doğruluk, özel hayat ve mahremiyet, hak ve adalet başlıkları altında toplanabilmektedir.

\section{Sağlık habercilik etiği}

Sağlık haberciliğinin belirleyicilerinden olan tıp ve basın, farklı olmalarına karşın benzerlikler gösteren iki alandır. Çünkü her iki alanda da asıl olan bağlllı, istek, bütünlük, yeterlilik, araştırma arzusu, güvenilirlik, sorumluluk ve savunmadır (Bertnard, 2004, 38). Gerek tup gerekse medya alanında sorumluluk kavramı, topluma karşı sorumluluk noktasında kesişmektedir. Bu ise sosyal (toplumsal) sorumluluk kuramının hatırlanmasını gerekli kılmaktadır.

Bireyin kendisi dışında kalan bireylere karşı sorumluluğunu ifade eden sosyal sorumluluk, "başkalarının iyiliği, refahı, iyi oluşuyla ilgili olma, başkalarına yardım etmeyi içeren içsel görev duygusu, sivil katılım ve başkalarına yönelik sorumlu tutumları içermektedir (Scales vd'den aktaran Özen, 2014,3)". Sosyal sorumluluk anlayışının temel amacı topluma yönelik fayda sağlamaktır. Bu bağlamda sosyal sorumluluk kuramı çerçevesinde değerlendirilen sorumluluğun, kişisel, örgüt, meslek ve toplumsal ilkeler olmak üzere dört dayanak noktası bulunmaktadır (Evers, 2010). Bunlardan mesleki ilkeler meslek örgütü içerisinde var olan ve mesleğin uygulanması sürecini kapsayan ilkeleri, toplumsal ilkeler de toplum içerisinde geçerli olan etik arka planı içermektedir.

Bu çerçevede Türk Tabipler Birliği Hekimlerin Toplumsal Sorumluluk Bildirgesi Sonuç Raporu'na değinmekte fayda bulunmaktadır. Raporda, "TTB her bireyin sağlık hakkına sahip olduğunu kabul eder ve bu hakkın hekimler için toplumsal sorumluluk doğurduğunu bildirir." denilmektedir. Bu sorumlulukları da şu şekilde sıralamaktadır: Toplumsal kaynakları akılcı kullanmak, 
sağlık sorunlarına bütüncül yaklaşmak, politika belirleyenleri uyarmak, kamuoyunda farkındalık yaratmak, aydın olarak demokratikleşme sürecine katılmak, sağlık alanlarındaki oluşumlara katılmak (Türk Tabipler Birliği, etik bildirgeler..., 2009, 54).

Sosyal sorumluluk kuramının en önemli özelliği, medyanın kamusal bir güç olarak sorumluluğunu vurgulamasıdır. Bu bağlamda medya, sadece tüketici ve hisse sahibine karşı değil, geniş ölçüde topluma karşı sorumlu tutulmaktadır. Diğer bir deyişle, sosyal sorumluluk kuramının temelinde medyanın gücü, etkisi ve konumu karşısında, topluma karşı sorumlu olma, tüm toplumsal tarafları adil biçimde temsil etme ve kamunun karar alabilmesi için yeterince bilgilendirilmesi zorunluluğu bulunmaktadır (Taş, 2010, 17).

Sağlık habercilik etiği ilkelerinden söz edilmesi gerektiğinde hem tıp hem de basın etiğine ait temel ilkeler hatırlanmalıdır. Başkalarına yararlı olmayı yükümlülük haline getiren (1) yarar sağlama, hekimin hastasına yönelik olarak neden olabileceği her türlü zarardan kaçınması gerektiğini anlatan (2) zarar vermeme, sağlık çalışanının hastasının mahremiyetine, gizliliğine saygı göstermesi, bilgilendirmeden uygulama yapmaması, dürüst davranması vb. uygulamalarla somutlaşan (3) özerkliğe sayg1, bireylerin toplumsal ve tıbbi olanaklardan adil olarak yararlanmalarını öngören (4) adalet ilkeleri tıp etiği ilkelerini oluşturmaktadır. Tarafsızlığı beraberinde getiren (1) objektiflik, haber üretiminde toplanan bilgi ve belgelerin doğrulanmasını anlatan (2) doğruluk, habere konu olan kişinin özel hayatın korunması ve haber kaynağına verilen sözler vb. konulanı içeren (3) özel hayat ve mahremiyet, hereksin eşit temsili olarak ifade edilen (4) hak ve adalet ilkeleri de basın etiği alanındaki temel ilkeleri oluşturmaktadır. Bu bağlamda sağlık haberciliği etik ilkelerinin tp ve basın alanında yer alan ilkelerin toplumsal sorumluluk ekseninde kesişen noktalarında aranması gerektiğini söylemek yanlış olmaz.

\section{Amaç}

Her ne kadar yurtdışında yapılan çalışmalarda, ayrı bir uzmanlık alanı olarak ele alınarak belirlenen ilkeler olsa da Türkiye'de, sağlık haberciliği/yayıncıllı̆̆ özelinde etik ilkeler ortaya konulmamıştır. Bu bağlamda, Türkiye'de sağlık haberciliği/yayıncılığı alanında etik ilkelerin neler olabileceğinin ortaya konulması çalışmanın problemini oluşturmaktadır.

Sağlık haberciliği/yayıncılığı alanında, ülkemizde açığı hissedilen sorumlu yayıncılık anlayışının gelişmesine yönelik önemli bir hareket noktası olarak görülen çalışma ile, Türkiye'de basın ilkeleri içerisinde ayrı bir uzmanlık alanı olarak sağlık haberciliği/yayıncılı̆̆ına ait temel belirleyici ilkeler tanımlanmış olacaktır.

\section{Yöntem}

Çalışmada, var olan bir durumu olduğu şekliyle betimlemeyi, bireylerin veya grupların atfettiği anlamları anlamayı amaçlayan nitel yaklaşım benimsenmiştir. Nitel çalısmalarda, yaklaşıma özgü veri toplama araçlarıyla (gözlem, görüşme, doküman analizi vb.) araştırılan konu gerçekçi ve bütüncül bir şekilde ortaya konulmaktadır. Nitel çalışmaların öne çıkan özelliklerinden ilki temel veri toplama aracının araştırmacı olmasıdır. Araştırmacı, tek kaynağa bağlı kalmak yerine verileri çoklu biçimlerini kullanarak -doküman incelemesi, gözlem, mülakat yoluyla- toplar, sonrasında verileri inceler, anlamlandırır ve veri kaynaklarını kapsayan kategori veya temaları belirleyerek analiz eder ve yorumlar (Creswell, 2014, 4 ve 185; Karasar, 2014, 77 ve 87).

Türkiye'de sağlık haberciliği etik ilkelerinin neler olabileceğinin sorgulandığı, bu anlamda verilerin doküman incelemesi ve görüşme yoluyla toplandığ çalışmanın modeli, nitel durum çalışması olarak belirlenmiştir.

Çalısma, amacı doğrultusunda üç aşamada kurgulanmıştır: (1) sağlık haberciliği ve etik ile ilgili çalışmaların öne çıktığı ülkelere ait basın ilkelerinin incelenmesi, (2) Yurt dışında yayınlanan ve sağlık habercilerine yönelik olarak hazırlandığı belirtilen medya kılavuzlarının incelenmesi, (3) uzmanlarla yarı yapılandırılmış görüşmeler gerçekleştirilmesi.

- Çalısmanın ilk aşamasını oluşturan basın ilkelerinin incelenmesinde; öncelikle sağlık haberciliğinin etkin olarak gerçekleştirildiği ülkelerin hangileri olduğu belirlenmiştir. Bu bağlamda 
ilk olarak gazetecilik ve etik konularında yapılan çalışmalar incelenmiş ve Doğu Akdeniz Üniversitesi İletişim Bilimleri Fakültesi Gazetecilik Bölüm Başkanı Prof. Dr. Süleyman İrvan, İstanbul Üniversitesi İletişim Bilimleri Fakültesi Genel Gazetecilik ABD Bölüm Başkan Yardımcısı Prof. Dr. Murat Özgen ve Türkiye'nin ilk ombudsmanı olan gazeteci Yavuz Baydar'ın isimlerine ulaşılmıştır. Belirlenen isimlerle iletişime geçilmiş ve yalnızca Süleyman İrvan'dan (2013) 'Kanaatimce, sağlık haberciliği konusunda Avrupa ve Kuzey Amerika'daki gazetecilik örgütlerinin etik kodlarına bakılması yeterlidir. Çünkü bu konu en çok buralarda etik açıdan sorgulanıyor" yanıtı alınmıştır. Ayrıca İrvan (2013), BBC yayın ilkeleri gibi kurumsal kodlara da bakılabileceğini belirtmiştir. Bu doğrultuda çalışma, özellikle Kuzey Amerika ve Avrupa ülkelerindeki basın ilkeleri ve sağlık haberciliği ile ilgili yapılan düzenlemeler çerçevesinde geliştirilmiştir. Yapılan literatür taramasında İrvan'ın (2013) belirttiği üzere sağllk haberciliği ve etik ile ilgili çalısmaların öne çıktığı ülkelerin Amerika, Kanada, İngiltere olduğu belirlenmiştir. Bunların yanı sıra, çalışmanın kapsamı dolayısıyla Türkiye, ilk basın konseyinin kurulduğu İsveç basın etik ilkeleri incelenen ülkeler olarak seçilmiş ve seçilen ülkelere ait etik kodlar incelenmiştir. (EK1)

- Çalışmanın ikinci aşamasını oluşturan medya kılavuzlarının incelenmesinde; özellikle yurt dışında yayımlanan, diyabet haberlerinin nasıl yapılması gerektiğinden obeziteye, ruh sağlı̆ı ile ilgili haberlerden prostat kanseri ile ilgili haberlere kadar birçok konu ile ilgili olarak sağlık haberinin hazırlanmasında başvuru kaynağı olarak kullanılabilecek kılavuzlara erişilmiştir. Kılavuzlar arasından çalışmanın amacı doğrultusunda sağlık habercilerine yönelik olarak hazırlandığı açıça ifade edilenler çalışma kapsamında incelenmiştir. (EK2).

- Çalışmanın üçüncü aşamasında ise çalışma kapsamında sağlık habercileri, doktor ve deontoloji alanında yetkin kişilerden "uzman görüşü” alınmıştır. Görüşüne başvurulan uzmanların belirlenmesinde, amaçlı örnekleme yoluna gidilmiştir.

Nitel çalışmalarda veri analizi, nitel çalışmanın gelişimindeki diğer kısımlarla, diğer bir deyişle veri toplama ve bulguları yazma ile birlikte ilerlemektedir (Creswell, 2014, 195). Bu kapsamda ulaşılan dokümanlara (basın ilkeleri ve medya kılavuzlarına ayrı ayrı) içerik analizi uygulanmıştır. İçerik analizi uygulamasinda öncelikle analize hazır hale getirilen basin ilkeleri tek tek incelenerek vurgulanan konular belirlenmiş ve kendi içerisinde gruplandırılmıştır. Sonrasında, literatür taramasında ortaya konulan basin temel ilkeleri (doğruluk, objektiflik, özel hayat ve mahremiyet, hak ve adalet) ve bu ilkeler dışında kalan konular (diğer) kategorileştirilmiş, alt kategoriler belirlenmiş ve kodlama kılavuzu oluşturulmuştur. Oluşturulan basin ilkeleri kodlama kılavuzunun denenmesi için ilk kodlama yapılmıştur. İlk kodlama sırasında, gerekli görülen düzenlemeler yapılmış, kodlama kılavuzuna son şekli verilmiştir. Bağımsız olarak iki farklı kodlayıcı tarafindan basın ilkelerine içerik analizi uygulanmış ve kodlayıcılar arası güvenirlik \%87 olarak hesaplanmıştır. Kodlama sonrasında elde edilen veriler yorumlanmıştır. Çalışmanın amacı doğrultusunda sağlık konusu özelinde basın ilkelerinde yer verilen açıklamalar ayrı bir başlık altında değerlendirilmiştir. 


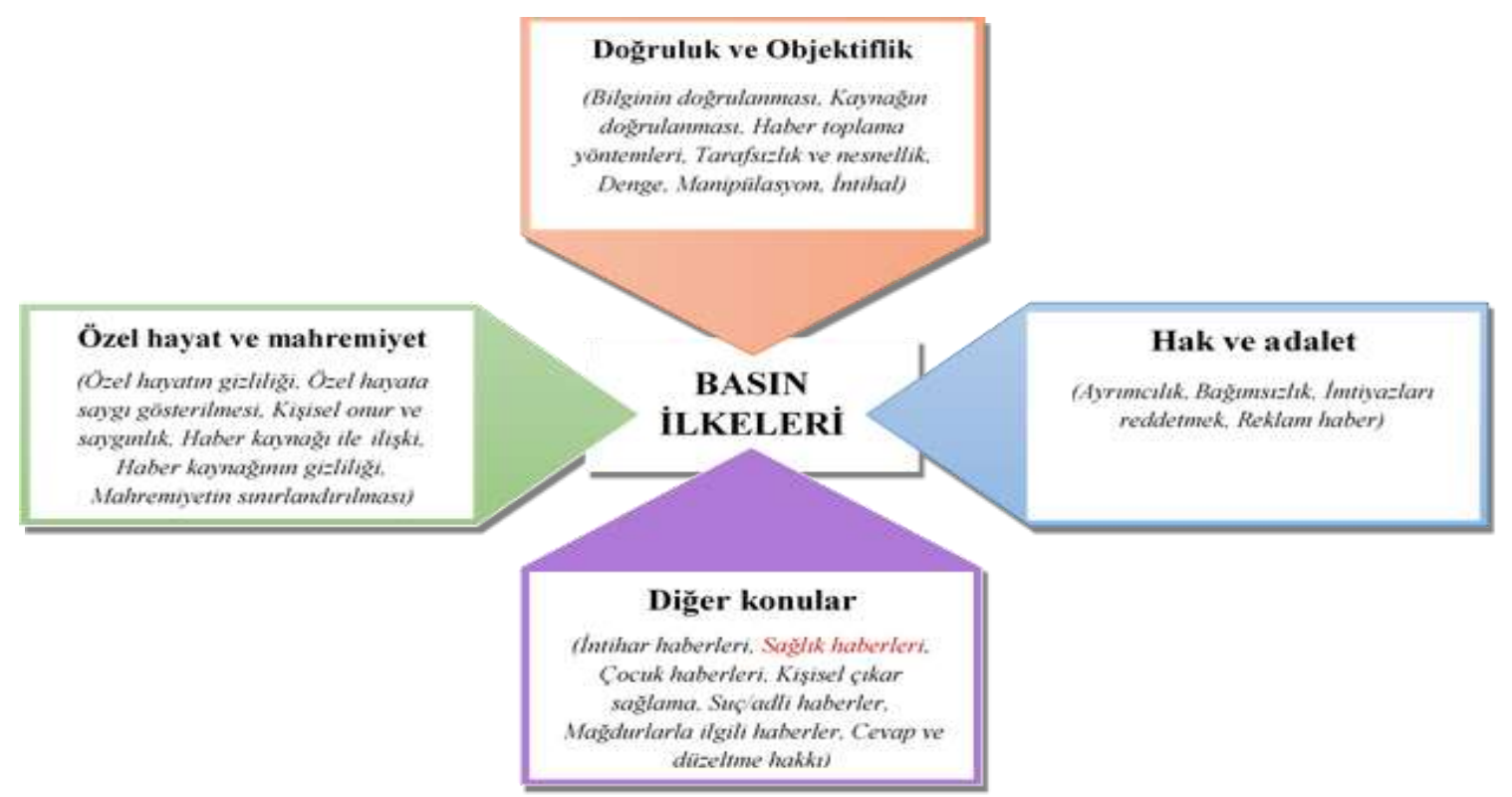

Şekil 1. Basın ilkelerinin analizinde kullanılan ana ve alt kategoriler

Çalışmada incelenen medya kılavuzlarına da aynı yöntemle içerik analizi uygulanmıştır. İlk olarak medya kılavuzlarının tamamı incelenmiş, vurgulanan konular belirlenerek kendi içerisinde gruplandırılmıştır. Kılavuzun yayınlanma gerekçesi, kılavuzda ele alınan hastalıkla ilgili verilen bilgiler, künye ve destek bilgileri, gazetecilere yönelik olarak vurgulanan konular olarak kategoriler belirlenmiştir. Alt kategoriler oluşturulurken "gazetecilere yönelik olarak vurgulanan konular ve yapılan öneriler" kategorisinin altında literatür taraması ile ortaya konulan sağlık haberciliği temel ilkeleri (doğruluk ve objektiflik, zarar vermeme, özel hayat ve mahremiyet, hakkaniyet) alt kategoriler olarak belirlenmiş ve bu kategorilerin altında yer alan konular belirlenmiştir. Medya kılavuzları için düzenlenen kodlama kılavuzu ile ilk kodlama yapılmış, gerekli görülen düzenlemelerle kodlama kılavuzuna son şekli verilmiştir. Bağımsız olarak iki farklı kodlayıcı tarafindan basın ilkelerine içerik analizi uygulanmış ve kodlayıcılar arası güvenirlik \%86 olarak hesaplanmıştır. Kodlama sonrasında elde edilen veriler yorumlanmıştır.

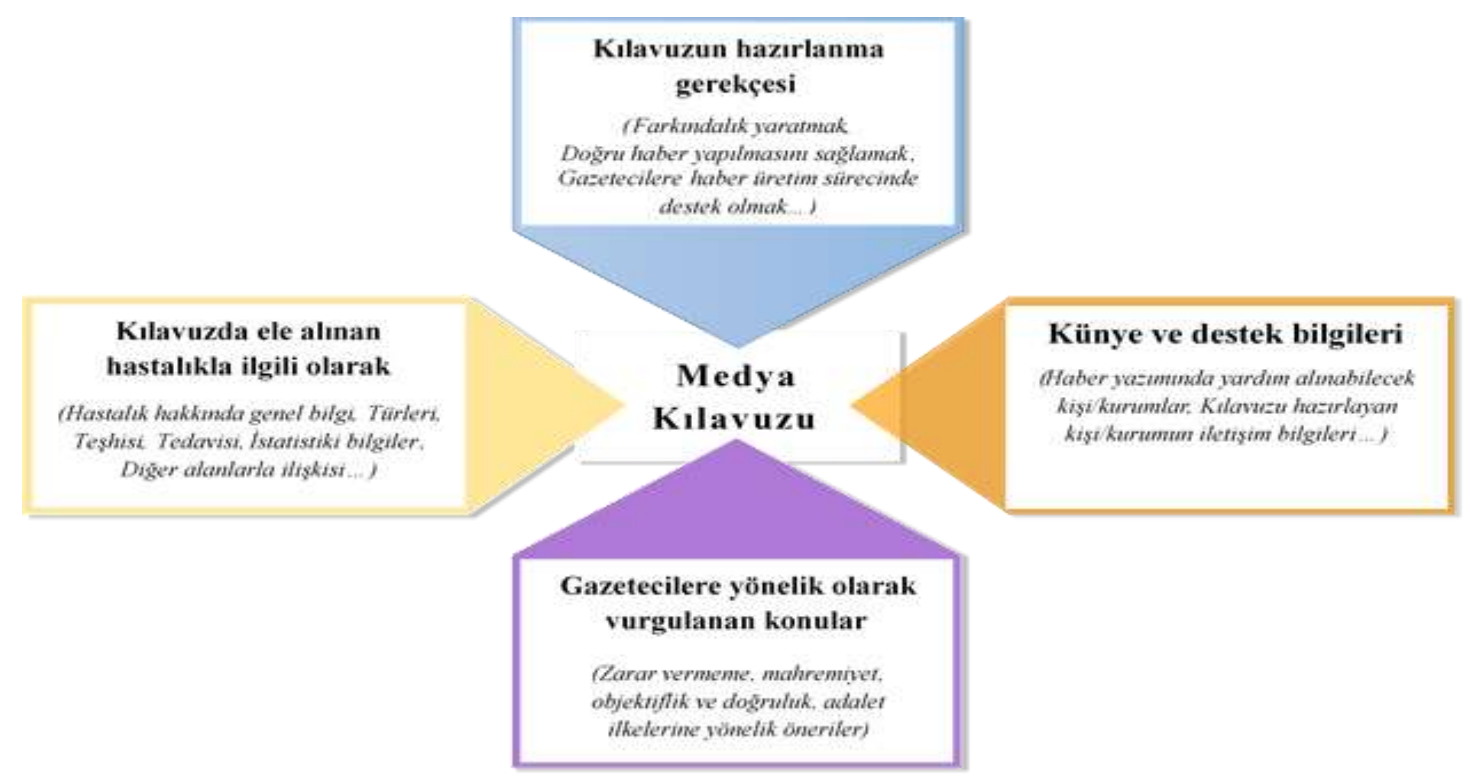

Şekil 22. Medya kılavuzlarının analizinde kullanılan kategoriler 
Çalışmada, uzmanlarla yarı yapılandırılmış görüşmeler gerçekleştirilmiştir. Görüşüne başvurulan uzmanların belirlenmesinde, amaçlı örnekleme yoluna gidilmiştir. Amaçlı örneklemede, araştırmacı amaçlarına en uygun yanıtı verebilecek kişiler arasından örneklemini seçmektedir. $\mathrm{Bu}$ nedenle amaçlı örnekleme, araştırmalarda konuyla ilgili aydınlatıcı bilgiye ulaşılması ve derinlemesine bir kavrayışın sağlanması açısından zengin bilgiye sahip olan durumların seçilmesine öncülük etmektedir (Patton, 2002, 45-46). Bu kapsamda, görüşü alınacak uzmanların seçilmesinde Türkiye'de faaliyet gösteren üç sağllk haberciliği derneği (ESAMDER, SMD, SILDER ${ }^{3}$ ) etkili olmuştur. Bu derneklere üye olan ve etkin olarak habercilik yapan sağlık muhabirlerine ulaşılmıştır. Ayrıca, derneklerle bağlantısı olmayan ancak sağlık haberciliğinde en eskiler arasında yer alan bir gazeteci, sağlık alanındaki dergilerde editörlük yapan iki doktor ve Biyoetik Derneği Başkanı'na da ulaşılmış ve görüşme talebi iletilmiştir. Toplamda on iki kişiye ulaşılmış ancak görüşmeyi kabul eden sekiz kişi ile yarı yapılandırılmış görüşmeler gerçekleştirilmiştir. Görüşmeler için ilk olarak elektronik postayla ulaşılan uzmanlara sonrasında telefonla ulaşılmış, yüz yüze görüşme isteği iletilmiştir. Yüz yüze görüşmeyi kabul eden uzmanlarla Eskişehir ve Ankara'da toplam altı saatlik görüşme gerçekleştirilmiştir. Yalnızca bir gazeteci ile yüz yüze görüşme imkânı bulunamamış ve görüşme elektronik posta yoluyla gerçekleştirilmiştir. Gerçekleştirilen yarı yapılandırılmış görüşmelerde uzmanlardan çalışma kapsamında geliştirilen sağlık haberciliği etik ilkelerini değerlendirilmeleri istenmiştir. Görüşmelerde katılımcıların bilgisi dahilinde ve onayları alınarak ses kayıt cihazı kullanılmıştır. Görüşmeler sonrasında ses kayıtları deşifre edilmiş ve uzmanların görüşlerine sağlık habercilik etik ilkelerinin belirlenmesi aşamasında yer verilmiştir.

\section{Bulgular}

Temel işlevleri insanların sağlık konusunda aydınlatılması, halk sağlığı konusunda farkındalık yaratılması ve bilinçlendirilmesi olan sağlık haberciliğinin sorumlulukları arasında zamanında, doğru ve güvenilir haberciliğin yanı sıra, kamu güvenini ve sağlığını sağlamak gibi özel bir sorumluluk da bulunmaktadır. Bu sorumluluk, topluma karşı olan sorumluluğun yanı sıra, hem gazetecinin hem de hekimin sorumluluğunu kapsamaktadır. Ancak, sağlık haberciliği ile ilgili yapılan çalısmalarda bu sorumluğun dışında haber üretimi yapıldığına işaret edilmekte ve sağlık haberlerinde karşılaşılan etik problemler şu şekilde belirlemektedir: Özel yaşama müdahale ve gizliliğin ihlali, rencide edici ifadelerin kullanılması, umut tacirliği yapılması, korku ve paniğe neden olan içerikler, sansasyonel içerikler, eksik veya hatalı bilgi verilmesi, bireysel sağlı tavsiyeleri verilmesi, ticari kaygılar ve sponsorluk ilişkileri. Gazetecilerin bağlamını tam olarak belirleyemediği, ana konuyu tam olarak anlamadığı, dengeli hikâye üretimi yapamadığı ve yazdıklarının etkisinin farkında olmadığı haberler.

Çalışma kapsamında, sağlık haberciliği etik ilkelerinin belirlenmesi adına sağlık haberciliğinin yoğun olarak yapıldığı ve buna bağlı olarak etik düzenlemelere önem verilen ülkelerin basın ilkeleri analiz edilmiştir. Basın ilkelerinde sağlık konusuna yer verilme oranının çok düşük olduğu belirlenmiştir. Bununla birlikte sağlık konusunda vurgulanan hususlar şunlardır:

- Kişinin haberden dolayı göreceği zararı öngörülmesi,

- Sansasyondan uzak, sahte umut verilmeden, duygu sömürüsü yapılmadan, özellikle ilaç tavsiyesi verilmeden haber yapilması,

- Tibbi araştırma sonuçlarının yayınlanmasında sponsor ilişkilerinin de farkında olunması,

- Haber toplamak için gerekli izinler alınmalı ve gizli ses/görüntü kaydı yapılmaması,

- Mahremiyete özen gösterilmesidir.

Aynı zamanda diyabet haberlerinin nasıl yapılması gerektiğinden prostat kanseri ile ilgili haberlere kadar, sağlık haberinin hazırlanmasında gazetecilere rehberlik etmesi için hazırlanan ve gazetecilere yönelik hazırlandığı açıkça ifade edilen medya kılavuzlarının analizi yapılmıştır. Yapılan analizde, medya kılavuzlarında gazetecilere yönelik olarak özellikle şu konuların vurgulandığ1 belirlenmiştir:

- Öncelikle hastalık ile ilgili özenli ve doğru dil kullanılması,

\footnotetext{
${ }^{3}$ ESAMDER: Eğitim ve Sağlık Muhabirleri Derneği; SMD: Sağlık Muhabirleri Derneği; SİLDER: Sağlık İletişsimi Derneği
} 
- Hastalık ile ilgi haberlerin kanıta dayalı olarak hazırlanması,

- Haberde genellemelerden kaçınılması,

- Ayrimcilik içeren veya destekleyen ifadelerin kullanılmamasi,

- Hastalıkla ilgili olarak efsanelerden ve yanlış yönlendirmelerden kaçınılması,

- Hastalıkla ilgili doğru terminolojinin kullanılması.

Çalışma kapsamında sağlık habercileri, doktor ve deontoloji alanında yetkin kişilerden oluşan uzmanlarla yarı yapılandırılmış görüşmeler gerçekleştirilmiştir. Görüşlerine başvurulan uzmanların sağlık haberciliği etik ilkeleri ile ilgili değerlendirme ve önerilerinde öne çıkan konular aynı zamanda Türkiye'de sağlı haberlerinde yaşanan etik sorunları da işaret eder niteliktedir:

- Sağlık haberciliği ciddi bir sosyal sorumluluk gerektirmektedir. Gazeteci doğru ve objektif haber verirken, habere konu olan bireyin kissilik haklarını koruma sorumluluğunu hatırından çıkarmamalıdır.

- Sağlık haberlerinde haber, başlık ve içerikte bağlamından koparılmamalı, bilgiler çarpitılmamalı, abartılmamalı ve yanıltıcı eklemeler yapılmamalı, mizansenlere başvurulmamalıdır.

- Sağlık haberlerinde, hastalık-hasta-tedavi öyküleri haberleştirilirken duygu sömürüsüne yol açılmamalı, ajite eden dil ve fotoğraf kullanımından kaçınılmalıdır.

- Sağlık ile ilgili haberlerde asparagas değil, bilimsel bulgularla desteklenen, doğru bilginin aktarılması gerekmektedir.

- Sağlık haberi, doğru bilgilerle ve çıkar gözetilmeksizin yapılmalıdır. Ismarlama haberler yoluyla reklam yapilmamalidir.

- Gazeteci, birbirinden farklı olan özel hayat ve mahremiyet kavramlarının ayrımını bilmeli ve haberlerinde dikkat etmelidir.

- Haberlerin herkes için hakkaniyetli olması, yani bir grup insanı öne çıkarmaması, yaftalamamasi gerekmektedir.

\section{Sonuç}

Tüm bu bilgiler 1şığında, zarar vermeme, doğruluk ve objektiflik, mahremiyet ve özel hayat, hakkaniyet ilkeleri Türkiye'de Sağglk Haberciliği Etik İlkeleri olarak ortaya konulmaktadır. Sağlık haberciliği etik ilkelerinin kapsamını şu şekilde belirlemek yerinde olacaktır:

Zarar vermeme ilkesi: Sağlık haberi hazırlarken gazeteci, topluma karşı sorumluluğunun bilincinde olarak, okuyucu/izleyicilerin sağlıklarının bozulmaması ve yaşam kalitesinin olumsuz yönde etkilenmemesi için özen göstermelidir.

Doğruluk ve objektiflik ilkesi: Gazeteci, temel amacı ve görevinin sorumluluğu gereği, doğruluğundan emin olmadığı bilgileri yayınlanmamalı, bilginin niteliği ile ilgili kurallara ve profesyonel gazetecilik kurallarına dikkat ederek ve tarafsı bir şekilde olayı aktarmalıdır.

Mahremiyet ve özel hayata sayg1 ilkesi: Doğru haber verirken, habere konu olan bireyin bir 'kişi' olmasından dolayı, kişinin sahip olduğu tüm hakları belirleyen kişilik haklarını koruması gerektiğinin bilincinde olan gazeteci, haberlerinde hem habere konu olan kişinin hem de haber kaynağının mahremiyetine ve özel hayatına saygilı olmalıdır.

Hakkaniyet ilkesi: Gazeteciliğin temel işlevi olan "haber verme", kişinin bilgi edinme hakkına dayanmaktadır. Bu anlamda, kişinin doğru bilgi edinmesi için gazetecinin sorumluluğu tarafsız ve doğru bilgi aktararak haber vermek, herkesin sağlık hizmetlerine eşit ulaşımına imkân vermek amacıyla yönlendirici ve yanıltıcı yayın yapmamaktır.

\section{Kaynakça}


Avc1, İ. B. ve Sönmez, M. F. (2013). Sağlik iletişimi bağlamında bireylerin televizyonda yayınlanan sağlık programlarını izleme alıșkanlıkları ve motivasyonları: Elazığ örneği. Gümüşane Üniversitesi İletisim Fakültesi Elektronik Dergisi, 2 (2), 119-138. http://egifder.gumushane.edu.tr/article/ view/5000006371 [Erişim tarihi: 22.11.2014]

Aydın, İ. (2012). Yönetsel mesleki ve örgütsel etik. (5. baskı) Ankara: Pegem Akademi Yayıncilık.

Aytaç, G. (2005). Edebiyat ve medya. Ankara: Hece Yayınları.

Baydur, M. (2010). Medyada "sağlıklı" insan sunumları: Popüler kültürde sağlıklı ve sürdürülebilir yaşam görünümleri. Yayınlanmamış Yüksek Lisans Tezi: Marmara Üniversitesi: İstanbul.

Berkarda, B. (2004). Erişkin kanserleri ve etik. Kanser ve etik. (Der: Ayhan O. Çavdar) Ankara: Türkiye Bilimler Akademisi Yayınları.

Bertrand, C.J. (2004). Medya etiğ̈. Ankara: Başbakanlık Basın-Yayın ve Enformasyon Genel Müdürlüğü.

Büken, N.Ö. ve Büken, E. (2002) Nedir şu tıp etiği dedikleri. STED, 11 (1), 17-20.

Cevizci, A. (2013). Uygulamah etik. İstanbul: Say Yayınları.

Creswell, J.W. (2014). Araştırma deseni. (Çev: S. B.Demir). Ankara: Eğiten Kitap.

Çı̆̆, Ü. ve Çı̆̆g, E.Ç. (2011). Haber Endüstrisi ve Gazetecilik Etiği. İş Ablakı Dergisi, 4 (8), 25-60.

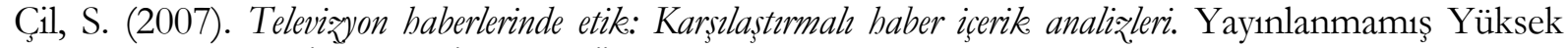
Lisans Tezi. İstanbul: İstanbul Üniversitesi.

Çobanoğlu, N. (2009). Kuramsal ve uygulamah t九p etiği. Ankara: Eflatun Yayınevi.

Code of ethics for press, radio and television in Sweden (2001) http://www.po.se/english/code-of-ethics/85code-of-ethics-for [Erişim tarihi: 26.04.2013]

Delius, H. (1990). Etik, Günümürde felsefe disiplinleri (Çev. ve Der.: D. Özlem) İstanbul: Ara Yayıncilık, ss.311-334.

Demir, M. (2008). Yazıl basında yayınlanan sağhlk haberlerinin kamuoyuna etkisi. Yayınlanmamış Doktora Tezi. İzmir: Ege Üniversitesi.

Erinç, S. M. (2008). Toplum ve insan. Ankara: Ütopya Yayınevi.

Etik, kodlanan etik ve pratiği. (2012). Ankara: TMMOB Elektrik Mühendisleri Odası Yayını.

Evers, H. (2010). Medya Etiği, içinde Televişyon haberciliğinde etik. Ed. Bülent Çaplı ve Hakan Tunçel, Ankara: Fersa Matbaacllik. http://ilef.ankara.edu.tr/etik/e-ders/ [Erişim Tarihi: 12.7.2012]

Friedman, D. B., Tanner, A. ve Rose I. D (2014). Health journalists' perception of their communities and implication for the delivery of health information in the news. Journal of Community Health. 39 (2), 378-385.

Fromm, E. (2006). Sağhkh toplum. (4. Baskı). (Çev.: Y. Salman ve Z. Tanrısever). İstanbul: Payel Yayınevi.

Half of medical reporting 'is subject to spin' (2012). http://www.nhs.uk/news/2012/09 September/Pages/Half-of-all-medical-reporting-is-subject-to-spin.aspx [Erişim Tarihi: 2.4.2014]

İşak, K. B.(2008) Hürriyet Gazetesi'nde sağlık haberciliği konusunda bir içerik analizi. Yayınlanmamış Yüksek Lisans Tezi. Eskişehir: Anadolu Üniversitesi.

Karagöz, K. (2009). Sağlık Haberlerinin Risk Alg1sı Oluşturma Bağlamında Etik Açıdan Değerlendirilmesi, Medya ve Etik Sempozyumu (Yayına haz̧rlayan: Mustafa Yağbasan). Elazığ:Fırat Üniversitesi, ss.189-207.

Karasar, N. (2014). Bilimsel arastırma yöntemi (26. baskı). Ankara: Nobel Yayın.

Kaya, A. ve Güler, B. (2012). Organ transplantation news on the press. 10th International Symposium Communication in the Millennium (e-book). İstanbul: İstanbul University. 79-94.

Kaya, A., Yüksel, E., ve Öğü, P. (2011). Sağlık haberlerinde mucize tedaviler. Selçuk İletişim Dergisi, 7 (1), 49-64.

Moseley, A. (2011). A'dan Z'ye felsefe (Çev:A. Süha) (3. Baskı). İstanbul: NTV Yayınları.

Oğuz, Y.N., Tepe, H., Büken, N.Ö. ve Kırımsoy Kucur, D. (2005). Biyoetik terimler söఇlïgü̈. Ankara: Türkiye Felsefe Kurumu Yayınları. 
Ögüt, P. (2013). Türkiye’de Sağlık Haberciliğinin Tarihsel Gelişimi ve Hürriyet Gazetesi Örneği. Yayınlanmamış Doktora Tezi. Eskişehir: Anadolu Üniversitesi.

Özen, Y. (2014). Kişisel ve sosyal sorumluluk bağlamında medya ve ahlak. Journal of European Education (JEE), 4, 2, http://dergipark.ulakbim.gov.tr/jee/article/viewFile/5000121660/ 5000112165 [Erişim Tarihi: 20 Mart 2016]

Özlem, D. (2010). Etik, ablak felsefesi. (2. Baskı). İstanbul: Say Yayınlar1.

Öztürk, N.K. (1998). Kamu yöneticilerinin kararlarında etik değerler. Amme İdare Dergisi, 31 (2), 81 92.

Patton, M. Q. (2002). Qualitative research \& evaluation methods (3rd edition). Hershey PA: SAGE Publications.

Piepper, A. (2012). Etiğe giriş (Çev: V.Atayman ve G.Sezer) (2.Baskı) İstanbul: Ayrınt Yayınları.

Southall, Betsy (2004). A Reporter's Guide: reporting about people with disabilities. http://www.wvdhhr.org/wvic/downloads/pdfs/media_guide.pdf [Erişim tarihi: 03.05.2014]

Taş, O. (2010). Medya Etiğinin tarihsel temelleri ve gelişimi, İçinde Televisyyon haberciliğinde etike. Ed. Bülent Çaplı ve Hakan Tunçel, Ankara: Fersa Matbaacilık. http://ilef.ankara.edu.tr/etik/eders/_[Erişim Tarihi: 12.7.2012]

Tepe, H. (2011). Etik ve meta etike (2. Baskı). Ankara: Türkiye Felsefe Kurumu Yayınları.

Türk Tabipler Birliği, Etik bildirgeler çalıştayı sonuç raporları (2009).Türk Kardiyoloji Derneği Arşivi, 37 (3), 51-66.

Yüksel, E., Kaya, A. Y., Koçak, A. ve Aydın, S. (2013). Türkiye'de sağllk konulu yaymonllk ilkelerinin belirlenmesi: kaynak, ileti ve hedef kitle bağlammda sağhk konulu yaymlarm analiz̨i. TÜBİTAK Projesi Sonuç Raporu. Proje no: 109K534. Eskişehir.

Sterling, C.H., O'Dell, C. ve Keith, M.C. (2010). The concise encyclopedia of American radio, New York: Talor\&Francis Group.

Süleyman İRVAN ile mail yoluyla gerçekleştirilen görüşme, 9 Mayıs 2013.

\section{EK1: Çalışma kapsamında analizi yapılan basın meslek ilkeleri}

1. Amerika'da en geniş tabanlı ulusal organizasyon olan Society of Professional Journalists'in (SPJ) yayınladığı etik ilkeler Code of Ethics

2. Amerika'da "en köklü kuruluşlar arasında yer alan hem de uygulanabilir standartlar ve etik üzerine yoğunlaşan (Sterling vd., 2010: 772)" The Radio-Television News Directors Association'in (RTND) yayınladığ Code of Ethics and Professional Conduct

3. Kanada'nın sesi olarak kendisini tanımlayan The Canadian Association of Journalism'in (CAJ) yayımlamış olduğu Ethics Guidelines

4. İngiltere Basın Şikâyetleri Komisyonu'nun (PPC) yayınlamış olduğu Newspaper and Magazıne Publishing in The U.K. Editors' Code of Practice

5. İngiltere Gazeteciler Birliği'nin (NUJ) yayınlamış olduğu İngiltere ve İrlanda gazetecilerinin davranış kurallarını belirten NUJ Code of Conduct

6. “İsveç’in önde gelen medya kuruluşları olan Gazete Yayıncıları Birliği, Dergi Yayıncıları Birliği, Gazeteciler Birliği ve Ulusal Basın Kulübü tarafından kurulan İşbirliği Komitesi’nin (Code of ethics for press..., 2001)" yayınlamış olduğu Code of Ethics for Press, Radio and Television in Sweden

7. Türkiye'de basın ile ilgili şikâyetlerde başvuru noktasında kullanılan Basın Konseyi Basın Meslek İlkeleri

8. Gazetecilerin temel görevleri ve ilkeleri ile gazetecinin doğru davranış kurallarının yer aldığı Türkiye Gazetecileri Hak ve Sorumluluk Bildirgesi 


\section{EK2: Çalışma kapsamında analizi yapılan medya kılavuzları}

1. Diabetes UK tarafindan 2012'de yayınlanan Diabetes in the news: A guide for journalists on reporting on diabetes.

2. National AIDS Trust (NAT) tarafindan 2010'da yayınlanan Guidelines for Reporting HIV: Advice for editors and journalists writing about HIV in the UK.

3. Mind and Rethink Mental Illness tarafindan desteklenen ve akıl sağllğı ile ilgili anti-stigma çalışmaları, kampanyaları yapan bir dernek olan Time to Change’in yayınlamış olduğu Media and reporting guides.

4. NUJ tarafindan ilk kez 1999 yllinda yayınlanan Guide for journalists and broadcasters reporting on Schizophrenia.

5. BodyWhys tarafindan yayınlanan Guidelines for the Media

6. NUJ tarafindan 2006 yllinda yayınlanan The reporting of mental health and suicide by the media: A practical guide for journalists.

7. The NSW Centre for Overweight and Obesity ve The University of Sydney tarafindan 2007'de hazırlanan Reporting obesity: a resource for journalists.

8. Mindframe, National Eating Disorders Collaboration ve Avustralyalı medya profesyonelleri işbirliği ile 2012 yllında hazırlanmış ve 2014 yılında güncellenmiş olan Reporting and Portrayal of Eating Disorders.

9. Mindframe tarafindan 2011'de yayınlanan Reporting suicide and mental illness resource for media professionals.

10. Mental Health and Suicide Prevention Programs Branch ve Australian Government Department of Health and Ageing için geliştirilmiş olan ve 2011'de yayınlanan Suicide and mental illness in the media.

11. Rudd Center for Food Policy and Obesity, TOS ve OAC tarafindan hazırlanan Guidelines for Media Portrayals of Individuals Affected by Obesity.

12. WVDDC desteği ile 2004 yllında hazırlanan A Reporter's Guide: Reporting About People with Disabilities.

13. Eating Recovery Center tarafindan hazirlanan The journalist's guide to eating disorders.

14. Research \& Training Center on Independent Living (RTC/IL) tarafindan 2001 yllinda yayınlanan Guidelines for Reporting and Writing about People with Disabilities.

15. Research \& Training Center on Independent Living (RTC/IL) tarafindan 2013 yllinda yayınlanan Guidelines: How to Write and Report About People with Disabilities.

16. Washington Regional Transplant Community (WRTC) tarafindan yayınlanan Reporting Guide.

17. Canadian Centre for Policy Alternatives tarafindan 2003 yılında yayınlanan A journalist's guide to covering prescription drugs: An essentials checklist for reporters and editors. 


\section{EK3:}

\section{Extended English Summary}

The media, which has the power to influence cultural changes, can attract the attention and direct behaviors of individuals who want to have a healthy, long life. The fact that individuals tend to believe in what they see on television, read in newspapers, or hear what they hear on radio puts a great responsibility on journalists. Therefore, health journalism requires a privileged responsibility and diligence.

Medical science and press, which are the determinants of health journalism, are two areas that show similarities although they are different.Because, in both areas, the main thing is commitment, desire, integrity, competence, desire to research, reliability, responsibility and defense.The concept of responsibility in the field of medical science and the media intersect at the point of responsibility towards society

In Turkey in recent years, "health publishing" studies on the rise. these studies began to concentrate on the field of communication science.

These studies focus on the different dimensions of the issue, such as the impact of health news/publications on the behavior of the individual and the evaluation of the press in general. However, it has not been dealt with in terms of how to behave ethically in relation to the health news/publishing in relation to the preparation and presentation of the news which has an impact on the life of the individual directly.

Purpose: Although studies conducted abroad, determined in accordance with the principles discussed in a separate area of expertise, though in Turkey, health journalism /broadcasting is not disclosed in the special ethical principles. With this study, which can also be seen as a starting point to improve the comprehension of responsible publishing and journalism in the health journalism area in Turkey, it's aimed to determine the principles of health journalism.

Method: Health journalism in Turkey questioned the ethics of what can happen, in this sense, document review and data collected through interviews that model of working has been identified as a qualitative case study. The model of the study is a qualitative case study where the data was collected through interviews and document review was determined. The study is designed in three stages: (1) examination of the press principles of the countries where health journalism and ethics studies come to the forefront, (2) examination of media guidelines prepared outside of Turkey for health journalists, (3) semi-structured interviews with experts.

Results: Within the scope of the study, to determine the ethical principles of health journalism, the press principles of the countries, where health journalism is intensively held and have ethical regulations in that field, are analyzed. It was determined that the rate of inclusion of health issues in the press principles was very low.

In order to guide the journalists in preparing the health news, the media guides, which are prepared for the purpose of guiding the journalists, have been analyzed and the subjects which are especially emphasized are determined.

In the media guidelines, it was determined that journalists were particularly emphasized: First of all, careful and accurate language related to the disease. Evidence-based preparation of news related to the disease. Avoiding generalizations in the news. Non-use of expressions with or without discrimination. Avoiding myths and misleading about the disease. Using the correct terminology for the disease.

In addition, the media guides prepared as a guideline for journalists in the preparation of health news were analyzed and particularly emphasized topics for journalists were determined. Semistructured interviews were also held with experts. The highlighted issues in opinions of interviewed 
experts about health reporting ethical principles evaluation and suggestions, were also found indicating the ethical problems experienced in health news in Turkey.

As a result, Health Journalism Ethics in Turkey defined as "no harm", "accuracy and objectivity", "privacy and private life" and "equity".

- Principle of "no harm": In preparing the health news, the journalist should be aware of the responsibility towards the society and not to impair the health of the readers/viewers and not to adversely affect the quality of life.

- Principle of "accuracy and objectivity": The journalist, who is aware of the fact that the person who is the subject of the news should protect his / her personal rights while reporting the news, should be respectful of the privacy and private life of both the person and the news source.

- Principle of "privacy and private life": The journalist, who is aware of the fact that the person who is the subject of the news should protect his / her personal rights while reporting the news, should be respectful of the privacy and private life of both the person and the news source.

- Principle of "equity": The journalist is responsible for informing the journalist about the correct and accurate information. 